\begin{tabular}{r|ll} 
AL-ISHLAH & Volume & $: 18$ \\
Jurnal Pendidikan Islam & Tahun & $: 1$ \\
& $: 2020$ \\
\hline
\end{tabular}

\title{
Analisis Pembelajaran Pendidikan Agama Islam Sekolah Dasar Luar Biasa di Samarinda
}

\author{
Siti Nasiah \\ Institut Agama Islam Negeri Samarinda \\ email:st_nasiah@yahoo.co.id
}

\begin{abstract}
This research aims to determine the implementation of Islamic religious education learning in children with special needs in special schools in Samarinda which includes how the application of the existing curriculum in schools and how teachers apply methods that are in accordance with the needs of students and who have various disorders. Student abnormalities in the study include blind, deaf, mentally retarded, blind, disabled, autistic, and students who have learning difficulties. The type of research developed in this study is a qualitative study of primary data sources for school principals and teachers who teach Islamic religious learning in exceptional elementary schools in Samarinda. While secondary data sources include documents related to school data, Islamic religious education learning tools, student learning outcomes assessment records. Data collection uses observation, interviews, and documentation. Data analysis uses data presentation, data reduction, and conclusions. The results were obtained that the learning of Islamic religion in children with special needs in Samarinda already uses curriculum 13. All SDLB schools in samarinda have no special teachers who teach Islamic religious education. The teacher makes lesson plans with curriculum curriculum adjusted material13, but the reality in the field teachers must still be able to adjust to the conditions of students, because of the limitations of diverse students so the teacher must also be able to adapt learning materials to the conditions of each child. Teacher teaching methods that are often
\end{abstract}


used include lecture methods, question and answer methods and demonstration methods. The teacher uses instructional media in explaining the material.

Keywords: Islamic religious teachings, children with special needs.

\begin{abstract}
Abstrak
Penelitian ini dilatarbelakangi bahwa pendidikan untuk semua anak, yang memberikan isyarat bahwa dalam memberikan pendidikan harus menyeluruh kepada semuanya tanpa ada pengecualian termasuk untuk anak yang mengalami keterbatasan, pembelajaran bagi anak-anak yang mempunyai kebutuhan khusus harus mempunyai keahlian khusus serta memiliki pengamatan yang cermat dalamminat dan bakat mereka sehingga tumpuan prestasi bukan kepada acuan akademik terstruktur sebagaimana untuk anak-anak normal. Tujuan penelitian untuk mengetahui pelaksanaan pembelajaranmeliputi kurikulum, metode guru mengajar yang disesuaikan dengan kebutuhan peserta didik yang memiliki kelainan beragam. Jenis penelitian ini merupakan penelitan kualitatif, pengumpulan data menggunakan observasi, wawancara, dan dokumentasi. Menggunakan penyajian data, reduksi data, dan kesimpulan untuk analisis data. Hasil penelitian sekolah SDLB di samarinda belum ada guru yang secara khusus mengajar pelajaran pendidikan agama islam. Guru kelas yang mengajar disesuaikan kurikulum k13, tapi kenyataan dilapangan guru tetap harus bisa menyesuaikan dengan kondisi peserta didik, karena keterbatasan peserta didik yang beragam jadi guru juga harus bisa menyesuaikan materi pembelajaran dengan kondisi setiap anak. Metode mengajar guru yang sering digunakan diantranya metode metode tanya jawab,ceramah, dan metode demonstrasi.
\end{abstract}

Kata kunci: pembelaran agama Islam, anak berkebutuhan khusus.

\title{
PENDAHULUAN
}

Pendidikan bersikap universal dan mencakup segala aspek, serta ditujukan kepada seluruh umat manusia. Peran penting yang dimiliki

AL-ISHLAH: Jurnal Pendidikan Islam 
Pendidikan yaitu pengembangan potensi iman dan potensi lainnya dalam diri manusia. ${ }^{1}$ UU Sisdiknas No 20 Tahun 2003 yang sebagaimana tertuang di dalamnya bahwa fungsi dari Pendidikan Nasional yaitu pembentukan peradaban serta watak martabatbangsa dan meningkatkan kemampuan untuk mencerdaskan segenap bangsa negara. Kemudian memiliki tujuan untuk pengembangan kemampuan peserta didik agar menjadi manusia yang bertaqwa dan beriman kepada Tuhan yang Maha Esa, sehat, mempunyai akhlak yang mulia, mandiri,berilmu, kreatif, cakap, demokratis, kemudian menjadi masyarakat yang bertanggung jawab". ${ }^{2}$ Pendidikan untuk semua (education for all/EFA) ${ }^{3}$ adalah isyarat bahwa dalam memberikan pendidikan harus untuk semuanya tanpa ada pengecualian termasuk pula untuk anak yang memiliki keterbatasan yang oleh sebagian orang dianggap tidak perlu diberikan pendidikan.

Pada anak-anak yang mempunyai kebutuhan khusus, kegiatan pembelajarannya merupakan suatu kegiatan yang menuntut para pendidik untuk cermat mengamati minat dan bakat mereka serta memiliki keahlian khusus dalam mendidik sehingga takaran prestasi bukan berpusat pada struktur prestasi akademik seperti pada anak-anak normal. ${ }^{4}$ Pengertian yang diberikan tersebut yaitu pembelajaran adalah suatu kegiatan yang penuh perencanaan dan terprogram dengan memakai seluruh kompetensi baik itu kompetensi sosial, kepribadian, profesional, dan juga kompetensi pedagogik

${ }^{1}$ Abdul Halik, Zulfianah Zulfianah, and Muh Naim. "Strategies of Islamic Education Teachers to Increase Students' Interest In Learning and Practicing in State Junior High School Lanrisang (SMPN) 1 Lanrisang, Pinrang." MADANIA: Jurnal Kajian Keislaman 22.2 (2018): 253-264. 2003.pdf

${ }^{2}$ Kelembagaan. Ristekdikti.go.id/wp-content/uploads/2016/08/UU_no 20 th

${ }^{3}$ Kusumawardhana, Indra, and Arry Bainus. "A Coxian Approach: Mengungkap Hegemoni Agenda "Education For All" Terhadap Negara Berkembang." Global Strategis 12.2 (2018): 53-68.

${ }^{4}$ Anggriana, Tyas Martika, and Rischa Pramudia Trisnani. "Kompetensi Guru Pendamping Siswa ABK Di Sekolah Dasar." Jurnal Konseling Gusjigang 2.2 (2016).

AL-ISHLAH: Jurnal Pendidikan Islam

Volume 18, Nomor 1, Juni 2020

P-ISSN : 2685-6581; E-ISSN : 1693-7449 
untuk mengarahkan peserta didik. ${ }^{5}$ Dalam pembelajaran untuk anak normal, guru harus memiliki keahlian yang khusus apalagi dalam kegiatan pembelajaran yang akan dilaksanakan pada anak-anak berkebutuhan khusus. ${ }^{6}$ Beberapa tahun berjalan terdapat fenomena yang muncul dimana telah tampil di depan wakil untuk komunitas dari anak-anak yang mempunyai kebutuhan khusus pada berbagai hal, dan juga tampak adanya rasa syukur yang lebih untuk kehidupan dibanding anak-anak yang normal. Demikian pula pada beberapa daerah pada umumnya masih seringkali anakanak yang memiliki kebutuhan khusus terpinggirkan darilingkungan anakanak yang normal.

Pendidikan agama menjadi salah satu pendidikan yang menjadi unsur penting dalam perkembangan anak berkebutuhan khusus. Kemudian Pendidikan agama Islam merupakan bimbingan yang berlandaskan dari hukum agama Islam bagi jasmani dan rohani untuk mengarah pada pembentukan kepribadian yang selaras dengan ajaranagama Islam, yang seluruh aspek kepribadiannya dijiwai oleh ajaran Islam. ${ }^{7}$ Tujuan dari adanya pendidikan agama adalah penanaman akhlak dan ketaqwaan serta penegakan kebenaran untuk pembentukan manusia yang mempunyai kepribadian dan budi yang luhur sesuai dengan ajaran Islam. ${ }^{8}$ Pendidikan agama Islam menunjukkan bahwa proses mengkondisikan dan menata pengetahuan, pengamalan, serta pemahaman ajaran agama yang dimiliki peserta didik. Aktualisasi nilai-nilai agama yang yang diajarkan dari

${ }^{5}$ Halik, Abdul, and Juliadi Juliadi. "PAI Learning Design Based on 2013 Curriculum and Implications for Learning Motivation of Students in State Senior High School 10 of Enrekang." International Conference on Natural and Social Sciences (ICONSS) Proceeding Series. 2019.

${ }^{6}$ Azizah, Nur. "Kompetensi Guru Pendidikan Khusus Dalam Pendidikan Transisi." JPK (Jurnal Pendidikan Khusus) 12.1 (2016): 1-13.

${ }^{7}$ Lihat Abdul Halik, "Paradigma Pendidikan Islam dalam Transformasi Sistem Kepercayaan Tradisional." AL-ISHLAH: Jurnal Pendidikan Islam 14.2 (2016).

${ }^{8}$ Muh Syakir, and Juliadi Juliadi. "Formulasi Pembelajaran PAI dan Implikasi Terhadap Motivasi Belajar Peserta Didik di SMA Negeri 10 Enrekang." AL-ISHLAH: Jurnal Pendidikan Islam 17.2 (2019): 159-180. 
pendidikan agama, dapat diterapkan oleh anak-anak yang mempunyai kebutuhan khusus pada kehidupan mereka sehari-hari. Dengan adanya pendidikan ini, anak bisa meningkatkan potensi yang mungkin tidak seluruhnya terdapat dalam diri mereka namunsetidaknya mereka dengan adanya pendidikan sanggup untuk berkarya.

Sekolah Luar Biasa (SLB) saat ini sedang menghadapi persoalan yang kaitannya dengan proses pembelajaran pendidikan agama Islam yaitu masih jarang guru Pendidikan Agama Islam yang memiliki kualifikasi pendidikan profesi khusus untuk guru Pendidikan Agama Islam Luar Biasa, buku-buku pelajaran untuk pembelajaran agama Islam di hampir seluruh sekolah luar biasa bagi anak-anak yang mempunyai kebutuhan khusus masih kurang. Kemudian sarana dan prasarana dengan kondisi yang belum memadai dan penggunaan strategi dalampembelajaran yang dirasakan masih kurang relevan karena kompetensi pendidik agama Islam dengan tindakan yang seharusnya diperoleh anak yang mempunyai kebutuhan khusus. Sehingga tujuan penelitian ini yaitu guna mengetahui bagaimana pelaksanaan pembelajaran PAI untuk anak yang mempunyai kebutuhan khusus. Kurikulum yang diterapakan bagi anak berkebutuhan khusus dan metode guru dalam mengajar peserta didik berkebutuhan khusus SDLB di Samarinda

\section{METODE PENELITIAN}

Jenis penelitian pada penelitian ini yaitu kualitatif (qualitative research). ${ }^{9}$ Sumber data penelitian terdiri atas sumber data primer yakni kepala sekolah dan pendidik PAI di Sekolah Dasar Luar Biasa yang ada di Samarinda, dan sumber data sekunder meliputi dokumen terkait data sekolah, perangkat pembelajaran PAI, catatan penilaian hasil belajar peserta didik. Teknik pengumpulan data yaitu wawancara, observasi, dan studi

9 Lexy J. Moleong, Metodologi Penelitian Kualitatif (Bandung: Remaja Rosdakarya, 2012), h. 330. 
dokumen. Wawancara dilakukan kepada Kepala Sekolah dan pendidik PAI di SDLB di Samarinda. Teknik observasi yang diterapkan adalah non partisipasif yakni peneliti hanya mengamati beberapa aktivitas pembelajaran PAI di Sekolah Dasar Luar Biasa. Uuji keabsahan data dilakukan dengan teknik triangulasi ${ }^{10}$, baik dari segi sumber, teori, teknik, maupun metode. Teknik analisis data bersifat deskriptif-kualitatif ${ }^{11}$, dengan teknik mereduksi data dengan pembuatan katogori dan koding, membuat simbol di mana simbol tersebut mempunyai arti berdasarkan topic penelitian yang diterapkan pada sekelompok kata atau paragraph dari transkip, antara katogori tersebut kemudian dicari hubungan atau kaitan (axial coding). ${ }^{12}$

\section{PEMBAHASAN}

\section{Analisis Pembelajaran Pendidikan Agama Islam di SDLB di Samarinda}

\section{Kurikulum Yang di Terapkan di SDLB di Samarinda}

Sekolah dasar luar biasa di Samarinda sudah menerapkan Kurikulum

K13, namun pada penerapnya tetap menyesuaikan kondisi anak. Kompetensi dasar PAI untuk SDLB meliputi:

a. Menyebutkan, menghafal, membaca dan mengartikan surat-surat pendek dalam Al-Qur'an, mulai surat Al-Fatihah sampai surat Al-'Alaq

b. Mengenal dan meyakini aspek-aspek rukun iman dari iman kepada Allah sampai iman kepada Qadha dan Qadar

c. Berperilaku terpuji dalam kehidupan sehari-hari serta menghindari perilaku tercela

${ }^{10}$ Sugiyono, Memahami Penelitian Kualitatif (Bandung: CV. Alfabeta, 2005), h. 246-252.

${ }^{11}$ Imam Gunawan, Metode Penelitian Kualitatif Teori dan Praktik (Jakarta: Bumi Aksara, 2013), h. 209.

12 Arbayah, Guru Kelas V SDLB -B Ruhui Rahayu.Wawancara. Samarinda. 15 Juli 2019 
d. Mengenal dan melaksanakan rukun Islam mulai dari bersuci (thaharah), sholat sampai zakat serta mengetahui tata cara pelaksanaan ibadah haji

e. Menceritakan kisah nabi-nabi serta mengambil teladan dari kisah tersebut dan menceritakan kisah tokoh orang-orang tercela dalam kehidupan nabi.

Kegiatan pembelajaran bermuara pada tercapainya tujuan pembelajaran. Tujuan PAI secara umum adalah meningkatkan keimanan dan ketaqwaan peserta didik, Sedangkan tujuan secara khusus PAI di SDLB adalah:

a. Menumbuhkan motivasi dan optimisme peserta didik tunadaksa dalam menjalani kehidupan.

b. Menumbuhkan sikap berserah diri, dan mensyukuri nikmat Allah, serta dapat menerima diri sendiri dengan segala kekurangannya, karena meyakini adanya hari akhir yang lebih kekal dari kehidupan di dunia, sehingga peserta didik memiliki semangat untuk berbuat baik agar mendapat kehidupan yang bahagia di sisi AllahSwt.

c. Mengembangkan perilaku peserta didik dengan sisa-sisa kemampuan yang ada.

d. Untuk meningkatkan ketaatan peserta didik kepada Allah Swt dengan cara menjalankan perintah-Nya dan menjahui larangan-Nya.

Pada aspek al-Qur'an, peserta didik diajarkan tentang surat A1Iklas, yang menjelaskan tentang ke-Esaan Allah. Seharusnya dalam aspek Fiqih, peserta didik diajarkan materi rukun Iman, sehingga nyambung antara satu aspek dengan aspek yang lainnya.Belum ada porsi yang seimbang antara aspek- aspek yang terdapat dalam mata pelajaran Pendidikan Agama Islam.

Orientasi pembelajaran lebih kepada Aspek cara melakukan ibadah sholat, budi pekerti, dan bukan penguasaan materi secara keseluruhan. Dengan kemampuan yang terbatas, anak-anak sulit menguasai seluruhaspek-aspek yang ada dalam mata pelajaran PAI, sehingga, untuk aspek-aspek yang lain tidak begitu mendapatkan porsi dalam pembelajaran. Menurut ibu Arbayah Guru kelas V di SDLB-B 
Ruhui rahayu, Guru lebih bersikap fleksibel dalam mendidik anak-anak yang memeiliki kebutuhan khusus. Tidak menekankan pencapaian nilai yang tinggi namun lebih kepada perubahan perilaku peserta didik ke arah yang lebih baik.Semua peserta didik di SLB pasti naik kelas meskipun perubahanya kurang signifikan, tapi aturanya tidak ada anak SLB yang tingal kelas atau tidak lulus, semua peserta didik dipastikan naik kelas. ${ }^{13}$

Materi disesuaikan kurikulum K13, tapi kenyataan dilapangan guru tetap harus bias menyesuaikan dengan kondisikan peserta didik, karena keterbatasan peserta didik yang beragam jadi guru juga harus bisa menyesuaikan materi pembelajaran dengan kondisi setiap anak. Prinsip penyederhanaan bukan pada bobotnya, akan tetapi pada jumlah secara kuantitas pada kompetensi dasar danindikator. Dalam kondisi riilnya, guru tetap membuat silabus dan Rencana Pelaksanaan Pembelajaran (RPP) sesuai dengan kurikulum. Persiapan itu menjadi acuan bagi guru dalam memenuhi tuntutan administratif, bukan sebagai patokan yang paten dalam mengajar di sekolah SDLB

\section{Pelaksanaan Pembelajaran PAI di SDLB Samarinda}

Persiapan pengajaran yang dilakukan pendidik terdiri dari kurikulum, silabus dan Rencana Pelaksanaan Pembelajaran.Kurikulum untuk SDLB adalah kurikulum khusus yang dirancang untuk SDLB yang disederhanakan. PAI sebagai salah satu mata pelajaran yang diajarkan di SDLB belum mendapat perhatian dan porsi yang cukup. PAI dilakukan oleh guru kelas masing-masing peserta didik Hasil wawancara dengan bapak Subowo kepala sekolah SDLB/B Ruhui Rahayu Pembelajaran PAI seharusnya diajarkan oleh guru khusus yang paham anak ABK tapi selama ini sekolah belum pernah menerima guru PAI, seharusnya ada kerja sama antara perguruan tinggi agama Islam yang mencetak sarjana PAI yang di tugaskan di SLB. Selama ini kami mengusulkan penambahan

15 Baderi, Kepala sekolah SDLB/ C Ruhui Rahayu, Wawancara, Samarinda, 25 Juli 2019. 
guru bidang studi PAI namun belum ada tindak lanjut dari pemerintah Kemenag. ${ }^{14}$ Sarjana PAI khusus ABK belum ada sekolahnya di Kalimatan Timur, seharusnya ada pelatihan khusus yang diberikan kepada calon Guru PAI sehingga guru mampu mamahami cara mengajar pada anak yang memiliki kelainan yan beragam.

Sekolah Dasar Luar biasa Untung Tuah C-D pernah menerima guru sarjana PAI, tapi hanya beberapa bulan saja gurunya mengajar, guru tersebut merasa tidak sanggup mengajar anak yang memiliki keterbatasan. ${ }^{15}$. Guru yang mengajar di SDLB harus butuh kesabaran yang ekstra, harus memiliki keikhlasan yang tinggi, harus mengajar dengan sepenuh hati jika tidak memili hal tersebut maka guru tidak akan bias mengajar anak yang memiliki keterbatasan fisik dan psikisnya. Sarjono yang merupakan sarjana PAI yang mengajar di SDLB-B Untung Tuah, menyatakan bahwa menjadi Guru yang mengajar di SLB itu harus diniatkan ibadah, mencari ilmu akhirat maka dunia akhirat akan didapat bersama-sama. Pemahaman itu yang menjadi pijakan kuat masih bertahan menjadi guru SLB tanpa berpikir berapa gaji yang didapatkanya, lantaran gaji yang diterima guru SLB kurang sesuai jika diukur dengan upah minimum Kota Samarinda. ${ }^{16}$

Untuk menjadi guru di SDLBmemang memerlukan kesabaran,dan keahlian dalam mendidik anak-anak berkelainan.Sedangkan SDM guru agama Islam,berasal dari PTAI (Perguruan Tinggi Agama Islam) yang notabene masih bersifat umum dan bukan bagian dari jurusan khusus seperti guru kelas yang merupakan alumni dari PLB(Pendidikan Luar Biasa).Kondisi demikian membuat guru-guru PAI yang mengajar di SDLB memerlukan pendidikan

${ }^{14}$ Baderi, Kepala sekolah SDLB/ C Ruhui Rahayu, Wawancara, Samarinda, 25 Juli 2019

${ }^{15}$ Agus Prasetyo, Kepala Sekolah SDLB/C-D Untung Tuah, Wawancara, Samarinda, 17 Juli 2019 2019

${ }^{16}$ Sarjono, Guru kelas SDLB Untung Tuah B. Wawancara, Samarinda, 22 Juli 
tambahan, seperti mengikuti pelatihan, seminar,atau peningkatan skill dalam menghadapi Anak Berkebutuhan Khusus.

Seorang guru harus memiliki Kemampuan dasar (basic ability) yaitu kemampuan yang untuk mampu mengidentifikasi dan memahami karakter anak luar biasa, mengetahui konsep sertadapat melaksanakanasesmenuntuk anak berkebutuhan khusussertamengembangkan alat asesmen tersebut. Guru PAI di SLB juga harus mempunyaikemampuan dasar untuk melakukan perancangan, pelaksanaan, dan evaluasi terhadapproses belajar mengajar bagi anak berkebutuhan khusus serta mampu melakukan manajemen pendidikan untuk SLB.

Pembelajaran peserta didik bisa melalui keteladanan atau peniruan.Indikasi darihal tersebutadalahsosok yangharusnya menjadi teladan dan cerminan bagi peserta didik dalam belajar dan bersikap dengan meniru adalah guru sebagaimana yang dicontohkan oleh Rasulullah Saw. Kegiatan pembiasaan sikap dan perilaku harus dimulai dalam pembelajaran sehingga dapat membentuk karakter yang ideal sedini mungkin.Seperti pembiasan peserta didik melakukan shalat dhuha berjamaah setiap pagi sebelum pembelajaran yang dilakukan guru kelas SDLB-B Ruhuai Rahayu ${ }^{17}$. Hasil yang dilaksanakan oleh pendidik dari prosespembiasaan ialah terbentuknya suatu kebiasaan yang baik dalam keseharianpeserta didik.Definisi dari Kebiasaan adalah sebagai tingkah laku yang bersifat tanpa perencanaan dahulu yang otomatis dan berlaku tanpa dipikirkan dan mengalirbegitu saja.

SDLB memiliki peserta didik dengan beragam kelainan, meliputi: Tuna Netra, Tuna grahita,Tuna Rungu, Tuna Laras, Tuna Daksa, Tuna Ganda, Tuna wicara, Autis, Kesulitan Belajar. Di Samarinda terdapat 13 sekolah SDLB yang menampung peserta didik berkebutuhan khusus, di antaranya SDLB Negeri Pembina, SDLB/A, Ruhuhui Rahayu, SDLB/B Ruhui Rahayu, SLB/C Ruhui Rahayu, SDLB Mutiara Kasih, SLB/B Untung Tuah, SLB/C-D Untung Tuah, SDLB Cemara Wilis, SDLB

\footnotetext{
${ }^{17}$ Erni Sulitiyaningsih, Guru kelas SDLB Ruhui Rahayu -B. Wawancara. Samarinda, 22 Juli 2019
} 
Tunas Harapan, SDLB Wisya Karya, SDLB Bhakti Pertiwi, SKH Pelita Bunda, SKH Istiqomah. ${ }^{18}$

Setiap sekolah menampung anak yang memiliki kelainan yang berbeda, sekolah yang menampung semua peserta didik yang memiliki kelainan yang berbeda yaitu SLB Ruhui rahayu dan SLB N Pembina. Ketiga sekolah tersebut memiliki banyak jurusan dan banyak kelas, perbeda dengan SDLB yang lain, masih ada peserta didik yang digabung dalam pebelajaranya, misalkan kelas rendah dijadikan satu kelas dan kelas tinggi juga dijadikan satu kelas. Dan peserta didik yang memiliki kelaianan yang berbeda dijadikan dalam satu kelas dalam pembelajranya

Subur, Kepala Sekolah SLB Widya Karya, menyatakan bahwa karena keterbatasan guru yang mengajar dan ruangan yang sedikit jadi terpaksa peserta didik digabungkan dalam pembelajaranya, dalam satu kelas ada sekitar 5 orang peserta didik yang memiliki kelainan yang berbeda yang bisa digabungkan. ${ }^{19}$ Semua SDLB di Samarinda terdapat peserta didik yang memiliki kelainan Tuna Grahita. Peserta didik Tuna Grahita pada umumnya untuk intelektualnya memiliki tingkat kemampuan yang di bawah rata-rata selain itu juga pada masa perkembangan hidupnya untuk perilaku adaptif mengalami hambatan. Karakteristik Tuna Grahita terdiri atas Tuna Grahita ringan, Tuna Grahita sedang dan Tuna Grahita berat.

SDLB A Ruhui Rahayu menampung peserta didik Tuna Netra (partially seing and legally blind), Tuna Netra atau disebut dengan anak yang mempunyai hambatan pada penglihatannya. Secara umum katagori tna netra terbagi dua yaitu: netra secara total dan netra yang sisa-sisa penglihatannya masih bisa digunakan.

Terdapat peserta didik yang memiliki prestasi yang rendah (specific learning disability). Atau yang memiliki kesulitan dalam belajar (learning

${ }^{18}$ Dinas Pendidkan Provinsi Kalimantan Timur, Dokumen Daftar Nama Sekolah SLB/Skh di Kalimantan Timur, Tahun 2019.

${ }^{19}$ Subur, Kepala Sekolah SDLB Bhakti Pertiwi. Wawancara. Samarinda, 8 Agustus 2019

AL-ISHLAH: Jurnal Pendidikan Islam

Volume 18, Nomor 1, Juni 2020

P-ISSN : 2685-6581; E-ISSN : 1693-7449 
disabilites). Guru memprogramkan bidang studi berdasarkan kurikulum yang ada namun sebagian dari peserta didik ini tidak memiliki kemampuan untuk menguasai pelajaran tersebut. Untuk pelajaran terdapat mayoritas dari mereka mempunyai nilai yang sangat rendah yang ditandai dengan hasil tes IQ mereka berada di bawah rata-rata normal. Golongan peserta didik pada katagori ini memiliki ciri antara lain sebagai berikut: kurangnya kemampuan dalam menulis, berbahasa dan bicara yang lancar karena adanya kelainan pada faktor psikologis. Merekasecara umum tidak sanggup untuk berfikir, selaku pendengar yang baik, menulis, mengeja huruf, untuk bicara dan membaca, bahkan untuk perhitungan matematika yang sederhana.

SDLB B Ruhui Rahayu Menampung peserta didik khusus tunarungu wicara (communication disorder and deafness) yaitu kelemahan peserta didik pada pendengaran dan kemampuan bicara sehingga berbeda dari anakanak yang memiliki kebutuhan khusus lainnya.Hal tersebut karena ketidakmampuan mereka untuk mendengar dan berbicara atau menggunakan panca indera mulutdan telinga. Karena itu apa yang dikatakan dan dimaksudkan oleh orang lain mereka tidak terlalu memahaminya. Seseorang yang mememiliki keterbatasan atau kehilangan kemampuan sebagian atau bahkan seluruhnya indera pendengaran mereka merupakan pengertian dari cacat pendengaran.

Kelainanyang disebabkan kemampuan berbahasa yang terhambat yang diakibatkan oleh adanya kerusakan pada otakmerupakan ciri darianak autis (autistic children).Anakautis pada umumnya mempunyai kelainan dalam mengungkapkan atau berbicara selain memiliki hambatan pada fungsi saraf serta kemampuan intelektual. Ketidakmampuan anak autis dalam berinteraksi dengan orang lain dan adanya keganjilan dengan perilaku mereka menjadi ciri yang dapat terlihat. Adapun ciri yang lain adalah suka untuk duduk menyendiri atau tidur bermalas-malasan,, mata sayup, memandang selalu ke bawah, muka pucat, jarang bertanya, tidak menunjukkan rasa takut, tidak memiliki keinginan yang bermacam-macam, dan juga tidak menyukai dan tidak peduli lingkungan sekitarnya kecuali pada sesuatu atau benda yang disenanginya. 
Tuna Daksa (physical disability) yaitu kelainan pada fisik yangpeserta didik Tuna Daksapada dasarnya kelainannya dikelompokkan pada dua kelompok yaitu kelainan pada sistim serebral dan kelainan pada sistem rangka dan otot. Padaanak tunadaksa secara umum mempunyai hambatan sebagai berikut :ketidakmampuan karena lemahnya kondisi fisik motorik berupagangguan koordinasi gerak dan untuk melakukan orientasi ruang, umumnya untuk menyesuaikan diri kurang sanggup karena saat melakukan interaksi mendapatkan tekanan-tekanan dari lingkungan sosialterlalu banyak kemudian ketidakmampuan dalam memecahkan suatu masalah. Tuna Ganda (multiple handicapped), Tuna Ganda yaitu peserta didik yang memiliki kombinasi keluarbiasaan seperti tunanetra dan tunagrahita, tunadaksa dan tunarungu, tunarungu dan Tuna Netra, Tuna Laras dan Tuna Grahita, atau lainnya yang memiliki kelainan dua kali lipat atau lebih.

\section{Metode Pembelajaran PAI pada Anak Berkebutuhan Khusus}

Metode pembelajaran disesuaikan dengan kondisi anak, berbagai metode dan media yang dapat di SDLB diantaranya,pertama Metode ceramah tidak menuntut anak untuk banyak bergerak. Peserta didik cukup duduk di kursi masing-masing dan mendengarkan penjelasan dari guru. Kedua Metode tanya jawab juga merupakan metode sederharna yang melengkapi metode ceramah. Guru PAI dapat mengetahui kemampuan peserta didik dalam menguasai materi melalui pemberian pertanyaan ketiga, metode demonstrasi yang akan melengkapi dua metode sebelumnya. Dengan peragaan, peserta didik akan lebih memahami penjelasan dari guru, dan bukan hanya mendapat gambaran secara absrtak. Sehingga, kesulitan mereka untuk memahami maksud perkataan guru dapat dipecahkan dengan menghadirkan alat peraga. Selanjutnya, untuk melatih tanggungjawab peserta didik, guru menerapkan metode pemberian tugas. Dengan metode ini, guru memberikan kepercayaan pada peserta didik untuk menyelesaikan suatu 
persoalan menyengktut materi pelajaran.Pada pelaksanaan metodeini,pemberian motivasi sangat dibutuhkan untuk menghindari peserta didik merasa putus asa dan menyerah karena merasa kesulitan.

Pemilihan Media Pembelajaran harus Sesuai dengan Materi Pembelajaran, Keberadaan media membantu guru PAI untuk menyampaikan materi pelajaran. Tanpa media, guru akan kesulitan untuk mendeskripsikan materi pelajaran. Pemilihan media berdasarkan penguasaan guru terhadap media yang digunakan dan kemampuan peserta didik utnuk memanfaatkan media yang digunakan. Sumber belajar paling utama bagi peserta didik adalah guru, penyeleggaraan buku-buku khusus untuk pendidikan di Sekolah Luar Biasa (SDLB) belum semuanya ada. Hanya ada sebagian sekolah yang memiliki buku pendidikan agama islam dan budi pekerti tapi masih menggunakan kurikulum KTSP. Namun dalam prakteknya materi dalam buku lebih disederhanakan lagi oleh guru disesuaikan dengan kondisi anak.

Kurikululm telah disusun, SKKD juga telah ada, namun bukubuku khusus PAI untukanak-anakABK belumada dimiliki setiap sekolah.Sejak dibuka program sekolah inklusi, anak-anak ABK tanpa disertai intelegensi dibawah normal dapat mengikuti pendidikan di sekolah umum. Dengan kurangnya buku-buku yang dirancang khusus untuk anak-anak ABK di SDLB maka, guru harus menyusun sendiri materi yang disesuaikan dengan kondisi anak. Materi PAI yang di ajarkan peserta didik ABK disesuakan dengan kemampuan peserta didik dan kondisi yang dimiliki peserta didik, selama ini peserta didik sekolah dasar belajar mengaji baru sampai pengenalan huruf alif ba $\mathrm{ta}^{20}$ Kemampuan belajar sangat erat kaitannya dengan aktivitas belajar yang dapat dilakukan ABK. Kemampuan belajar ini sangat penting diperhatikan untuk penetapan media pembelajaran, agar media tersebut dapat mempermudah belajar ABK.

${ }^{20}$ Dewi Endah Lestari, Guru Kelas SKH Pelita Bunda, Wawancara, Samarinda, 8 agustus 2019.

AL-ISHLAH: Jurnal Pendidikan Islam

Volume 18, Nomor 1, Juni 2020

P-ISSN : 2685-6581; E-ISSN : 1693-7449 
Media pembelajaran yang dapat digunakan di SDLB disesuaikan dengan keterbatasan yang dimiliki peserta didik diantaranya ABK dengan keterbatasan penglihatan lebih tepat bila digunakan jenis media audio. ABK dengan keterbatasan pendengaran lebih tepat menggunakan jenis media cetak/gambar, ABK dengan keterbatasan mental lebih tepat menggunakan jenis multi media dan benda konkrit. Jenis media pembelajaran yang sesuai digunakan ABK dengan gangguan penglihatan menurut Yeni M \& Caryoto, di antaranya ${ }^{21}$ media pembelajaran yang sesuai untuk ABK buta total: peta timbul, radio, audio, penggaris braille, blokies, papan baca, model anatomi mata, meteran braille, botol aroma, bentuk-bentuk geometri, tape recorder, media 2 dan 3 dimensi, lingkungan sekitar anak, komputer dan printer braille. Low vision: CCTV, Magnifier Lens Set, View Scan, Televisi, Microscop

Media pembelajaran yang sering digunakan di SDLB-A Ruhui rahayu menurut bapak suwito di antaranya al quran Braille, Iqro Braile , audio, peserta didik lebih mudah mengahfal surah surah pendek melalui pendengaranya, ada peserta didik kami yang sudah hafal alquran surah pendek jus $30^{22}$. Peserta didik yang memiliki keterbatsan penglihatan tapi pendengaranya masih berfungsi dengan baik.Pembelajaran lebih mudah diserap peserta didik melalui suara.Untuk mencapai hasil belajar PAI, peserta didik lebih banyak belajar melalui keterampilan mengucapkan, bergerak dan menghafal. Karekteristik media pembelajaran yang digunakan dalam pembelajaran PAI harus memiliki sifat sebagai berikut: a) visible (dapat dilakukan), b) interesting (menarik), c) useful (bermanfaat), d) structured (susunan keunikannya), e) accurate (tepat), dan f) prinsip kemudahan belajar peserta didik. ${ }^{23}$ Media pembelajaran diharapkan dapat

${ }^{21}$ Yeni Meimulyani \& Caryoto, Media Pembelajaran Adaptif bagi Anak Berkebutuhan Khusus (Jakarta: PT Luxima Metro Media, 2013), h. 50-51

${ }^{22}$ Suwito, Guru Kelas SDLB -A Ruhuai Rahayu, Wawancara, Samarinda, 19 Juli 2019.

${ }^{23}$ Ishartiwi, Pengembangan Media Pendidikan Agama Islam Bagi Anak Berkebutuhan Khusus (Yogyakarta: FIP-UNY, Bahan Pelatihan PPPG SLB, 2008), h. 4 
memotivasi anak ABK untuk semangat belajar dengan berbagai keterbatasan.

Keberagaman perbedaan yang ada pada anak berkebutuhan khusus dapat dilihat dari berbagai aspek di antaranya: perbedaan minat dan perhatian; perbedaan cara belajar (kinestetik, auditif, visual dan intelektual); dan perbedaan kecerdasan. Belajar untuk fokus, mengikuti arahan untuk berfokus dan patuh terhadap suatu masalah yang akan dihadapi. Hal ini diperlukan karena para anak berkebutuhan khusus dengan karakteristik autis sangat sulit untuk mencapai fokus.

\section{Evaluasi Hasil Belajar PAI pada Anak Berkebutuhan Khusus}

Alat penilaian untuk pembelajaran PAI yang digunakan yaitu penilaian tertulis, penilaian sikap, dan unjuk kerja. Penilaian tertulis dilakukan dengan tes tertulis. Tes tertulis merupakan tes dimana soal dan jawaban yang diberikan kepada peserta didik dalam bentuk tulisan. Seperti yang diungkapkan ibu Titik "peserta didik diberi soal tes berbentuk pilihan ganda kemudian peserta didik menjawab dengan pilihan yang sesuai secara tertulis, isyarat atau diberi tanda". ${ }^{24}$. Dalam menjawab soal peserta didik tidak selalu merespon dalam bentuk menulis jawaban tetapi dapat juga dalam bentuk lain seperti memberi tanda, warna, dan isyarat. Penilaian Peserta didik tunarungu lebih mudah diajarkan dengan menulis, mereka belajar menggunakan tulisan dan bahasa isyarat. Berbeda dengan peserta didik Tuna Grahita yang lebih susah belajar menulis, jadi penilainya harus disesuaikan kondisi anak. Jumlah soal juga disesuaikan dengan masingmasing kebutuhan anak berkebutuhan khusus, yang dibedakan antara ABK yang satu dengan ABK yang lainnya.

Tes tertulis juga dilakukan pada saat Ujian Akhir Nasional, bagi peserta didik ABK disesuaikan dengan kemampuan peserta didik berkebutuhan khusus. Jika peserta didik belum mampu menulis ada guru pendamping yang membimbingnya untuk menjawab soal ${ }^{25}$. Selain berada

${ }^{24}$ Titik, Guru Kelas SDLB-B Ruhui Rahayu, Wawancara, Samarinda, 19 Juli 2019.

${ }^{25}$ Titik, Guru Kelas SDLB-B Ruhui Rahayu, Wawancara, Samarinda, 19 Juli 2019.

AL-ISHLAH: Jurnal Pendidikan Islam

Volume 18, Nomor 1, Juni 2020

P-ISSN : 2685-6581; E-ISSN : 1693-7449 
dalam ruangan khusus, peserta didik ABK juga didampingi pengawas dan guru pendamping. Penilaian sikap yang perlu dicatat dalam buku cacatan Guru tentang ABK adalah kejadian kejadian yang menonjol yang berkaitan dengan sikap, perilaku, dan unjuk kerja peserta didik, baik yang positif maupun negatif. Kejadian yang menonjol adalah kejadian-kejadian yang perlu mendapat perhatian, atau perlu diberi peringatan dan penghargaan alam rangka pembinaan peserta didik.

Ketercapaian tujuan pembelajaran dapat dilihat dari evaluasi hasil belajar yang dilakukan. Jika di SDLB tujuan lebih mengarah kepada Aspek sikap cara melakukan ibadah sholat yang baik, maka evaluasi yang dilakukan lebih kepada penilaian sikap dan perbuatan peserta didik. Dalam mempelajari suatu materi pelajaran, guru memberikan nilai lebih kepada usaha peserta didik untuk belajar atau menguasai suatu materi,bukan hasilnya.Seperti evaluasi yang di lakukan di kelas ibu suharti ketika materi praktek wudhu,anak- anak tidak bisa berwudhu seperti orang-orang normal pada umumnnya, sehingga guru juga tidak bisa memberikan nilai yang buruk karena mereka salah melakukan gerakan wudhu, akan tertapi, lebih kepada usaha anak-anak untuk melakukan praktek wudhu tersebut. ${ }^{26}$ Guru akan memberikan nilai baik jika anak-anak sudah mau berusaha dan mau menuruti perintah guru, sehingga evaluasi lebih kepada proses, bukan hasil.

Penilaian menggambarkan baik atau buruknya peserta didik dapat dilihat dari indicator keberhasilan peserta didik mengikuti pelajaran dapat dilihat diri pribadi masing-masing individu. Setelah mengikuti mata pelajaran PAI, peserta didik menjadi lebih mengerti tanggungjawabnya sebagai umat Islam. Sejumlah fenomena-fenomena berkaitan dengan hasil pendidikan agama Islam di SDLB Samarinda. Peserta didik kelas enam telah mengenal huruf-huruf Hijaiyah, mereka

2019.

${ }^{26}$ Suharti, Guru kelas, SDLB-B Untung Tuah, Wawancara, Samarinda, 27 Juli 
mengulanginya mengaji di rumah, dan menjalankan shalat 5 waktu (dilihat dari buku catatan pribadi). Meskipun mereka memiliki intelegensi yang rendah, Namun mereka mengerti bahwa puasa itu wajib dilakukan sehingga mereka berpuasa menurut kemampuan mereka. Pengamatan unjuk kerja perlu dilakukan dalam berbagai konteks untuk menetapkan tingkat pencapaian kemampuan tertentu. Penilaian unjuk kerja yang dilakukan bapak Sarjono" Bagi peserta didik tunagrahita dan autis, dimodifikasi menjadi berani tampil ke depan kelas dan menceritakan kembali isi cerita seperti yang ada di buku. Penilaianya lebih kepada peserta didik tampil di depan kelas. ${ }^{27}$

Untuk menilai kemampuan berbicara peserta didik misalnya, perlu dilakukan pengamatan atau observasi berbicara yang beragam, seperti diskusi dalam kelompok kecil, dan menceritakan kisah dengan bahasanya sendiri. Untuk hafalan surat-surat pendek, ABK tidak dituntut untuk menghafal surat dalam batas waktu tertentu. Tetapi melalui pengulangan secara konsisten di bawah bimbingan Guru sesuai dengan kemampuan anak. Guru harus secara rutin membimbing bacaannya.Pada akhir semester, Guru menyimpulkan hasil catatan, sebagai bahan deskripsi dari sikap, perilaku, dan unjuk kerja peserta didik dalam semester tersebut untuk mata pelajaran agama islam dan budipekerti yang dimiliki peserta didik ABK. Deskripsi dari sikap, perilaku, dan unjuk kerja peserta didik ini menjadi bahan atau pernyataan untuk diisi dalam kolom catatan guru pada rapor peserta didik.

\section{KESIMPULAN}

Pelaksanan pembelajaran PAI bagi anak berkebutuhan khusus di SDLB Kota Samarinda,dilakukan oleh guru kelas, belum ada guru khusus bidang studi pendidikan agama islam, kemampuan yang harus dimiliki guru untuk dapat memahami dan mampu mengidentifikasi anak luar biasa,

\footnotetext{
${ }^{27}$ Sarjono, Guru Kelas SDLB-B Untung Tuah, Wawancara, Samarinda, 8 Juli 2019.
} 
memahami konsep dan mampu mengembangkan alat asesmen serta melakukan asesmen anak berkebutuhan khusus. Selain itu, kemampuan dasar guru agama di SLB adalah mampu merancang, melaksanakan, dan mengevaluasi pembelajaran bagi anak berkebutuhan khusus,dan program bimbingan dan konseling bagi anak berkebutuhan khusus

Kurikulum yang diterapakan pada anak berkebutuhan khusus di SDLB Samarinda sudah menerpakan kurikulum 13. Kegiatan pembelajaran bermuara pada tercapainyatujuan pembelajaran.Tujuan PAI secara umum adalah meningkatkan keimanan dan ketaqwaanpesertadidik.Orientasi pembelajaran lebih kepada Aspek cara melakukan ibadah sholat, budi pekerti, dan bukan penguasaan materi secara keseluruhan. Dengan kemampuan yang terbatas,anakanaksulitmenguasaiseluruhaspek-aspekyangadadalammatapelajaran PAI, sehingga, untuk aspek-aspek yang lain tidak begitu mendapatkan porsi dalam pembelajaran

Metode guru dalam mengajar peserta didik anak berkebutuhan khusus di SDLB Samarinda menggunaan metode ceramah, metode tanya jawab dan metode demonstrasi. Guru menggunakan media pembelajaran dalam menjelaskan materi, pemilihan Media Pembelajaran harus Sesuai dengan kondisi anak. Pemilihan media disesuiakan dengan keterbatasan yang dimiliki peserta didik diantaranya ABK dengan keterbatasan penglihatan lebih tepat bila digunakan jenis media audio.ABK dengan keterbatasan pendengaran lebih tepat menggunakan jenis media cetak/gambar, ABK dengan keterbatasan mental lebih tepat menggunakan jenis multi media dan benda konkrit.

\section{REFERENSI}

Anggriana, Tyas Martika, and Rischa Pramudia Trisnani. "Kompetensi Guru Pendamping Peserta didik ABK Di Sekolah Dasar." Jurnal Konseling Gusjigang 2.2 (2016). 
Azizah, Nur. "Kompetensi Guru Pendidikan Khusus Dalam Pendidikan Transisi." JPK (Jurnal Pendidikan Khusus) 12.1 (2016): 1-13.

Daradjat, Zakiah. Ilmu Pendidikan Islam. Cet. Ke-2; Jakarta: Bumi Aksara, 1992.

Delphie, Bandi. Pembelajaran Anak Berkebutuhan Khusus Dalam Setting Pendidikan Inklusi. Bandung, PT. Refika Aditama, 2006.

Depdiknas. Pedoman Penilaian Pendidikan Khusus, Jakarta: Depdiknas Pusat kurikulum Badan Penelitian danPengembangan Departemen Pendidikan Nasional, 2006.

Gunawan, Imam, Metode Penelitian Kualitatif Teori dan Praktik. Jakarta: Bumi Aksara, 2013.

Haidz JM "Reformasi Pembelajaran PAI Ke Arah Edutainment" dalam http:// koranpendidikan.com/artikel-1237-Reformasi-PembelejaranPAI-Kearah-dutainment.html tanggal 20 April 2014.

Halik, Abdul, and Juliadi Juliadi. "PAI Learning Design Based on 2013 Curriculum and Implications for Learning Motivation of Students in State Senior High School 10 of Enrekang." International Conference on Natural and Social Sciences (ICONSS) Proceeding Series. 2019.

Halik, Abdul, Zulfianah Zulfianah, and Muh Naim. "Strategies of Islamic Education Teachers to Increase Students' Interest In Learning and Practicing in State Junior High School Lanrisang (SMPN) 1 Lanrisang, Pinrang." MADANIA: Jurnal Kajian Keislaman 22.2 (2018): 253-264.

Halik, Abdul. "Paradigma Pendidikan Islam dalam Transformasi Sistem Kepercayaan Tradisional." AL-ISHLAH: Jurnal Pendidikan Islam 14.2 (2016).

Ishartiwi. Pengembangan Media Pendidikan Agama Islam Bagi Anak Berkebutuhan Khusus. Yogyakarta: FIP-UNY, Bahan Pelatihan PPPG SLB, 2008. 
Jamila K. A. Muhammad. Special Education for Special Children. Ter. Edy Sembodo. Cet. I; Jakarta: Hikmah, 2008.

Kusumawardhana, Indra, and Arry Bainus. "A Coxian Approach: Mengungkap Hegemoni Agenda "Education For All" Terhadap Negara Berkembang." Global Strategis 12.2 (2018): 53-68.

Moleong, Lexy J. Metodologi Penelitian Kualitatif. Bandung: Remaja Rosdakarya, 2012.

Sagala, Syaiful. Konsep dan Makna Pembelajaran. Cet V; Bandung: Alfabeta, 2007.

Sudarwan, Danim. Menjadi Penelitian Kualitatif. Bandung: Pustaka Setia, 2002

Sugiyono. Memahami Penelitian Kualitatif. Bandung: CV. Alfabeta, 2005.

Sukarso, Ekodjatmiko., dkk. Acuan Penyelenggaraan Pendidikan Luar Biasa. Jakarta: Dirjen PLSB. 2001.

Sukarso, Ekodjatmiko., dkk. Assesmen Anak Berkebutuhan Khusus. Jakarta: Dirjen PSLB, 2001.

Syakir, Muh, and Juliadi Juliadi. "Formulasi Pembelajaran PAI dan Implikasi Terhadap Motivasi Belajar Peserta Didik di SMA Negeri 10 Enrekang." AL-ISHLAH: Jurnal Pendidikan Islam 17.2 (2019): 159-180.

Usman, Basyiruddin. Metodologi Pemblajaran Agama Islam. Jakarta: Ciputat Pers, 2002.

Yeni Meimulyani \& Caryoto, Media Pembelajaran Adaptif bagi Anak Berkebutuhan Khusus (Jakarta: PT Luxima Metro Media, 2013

Yeni Meimulyani \& Caryoto. Media Pembelajaran, Jakarta: Penerbit Luxima, 2013. 